\title{
Induction of Cassava Somatic Embryogenesis in Liquid Medium Associated to Floating Membrane Rafts
}

\author{
Elizabete Keiko Takahashi ${ }^{1}$, Adilson Kenji Kobayashi ${ }^{1}$ and Luiz Gonzaga Esteves Vieira ${ }^{1 *}$ \\ ${ }^{1}$ Laboratório de Biotecnologia - Área de Ecofisiologia - Instituto Agronômico do Paraná (IAPAR), Caixa Postal \\ 481 CEP 86001-970 - Londrina - PR, Brasil.
}

\begin{abstract}
The objective of this study was to examine the effect of two culture systems, liquid medium associated to floating membranes and solid medium, both supplemented with different concentrations of 2,4-D, in the induction of somatic embryogenesis of cassava (Manihot esculenta Crantz). Only $28 \%$ of the young leaf lobes (with $9 \mu M$ 2,4-D) were induced to form organized embryogenic structures (OES) with membrane rafts, compared to $50 \%$ of the explants presenting this type of tissue in solid medium with $36 \mu M$ of 2,4-D. Despite the lower response observed in liquid medium with membrane, the amount of OES/explant in all 2,4-D concentrations was higher than solid medium. Based on the results and considering the high cost of the membrane rafts, this system was not distinctly superior than solid medium for inducing somatic embryogenesis in cassava.
\end{abstract}

Key words: Manihot esculenta, Somatic embryogenesis, Membrane rafts, Organized embryogenic structures (OES).

\section{INTRODUCTION}

Cassava (Manihot esculenta Crantz) is a tropical perennial shrub cultivated for its starchcontaining tuberous roots. It is used as a staple food by more than 500 million people (Roca $e t$ al., 1992). Because of its tolerance to adverse environmental conditions, cassava can be cultivated in low fertility soils. Despite its economic importance for tropical countries, until recently, little emphasis has been placed on cassava breeding programs.

Implementation of tissue culture techniques for conventional breeding of cassava is very important to improve its efficiency and speed. Studies on somatic embryogenesis of cassava were first reported by Stamp \& Henshaw (1982). Since then, a variety of improvement has been reported, such as the induction of cyclic embryogenesis (Raemakers et al., 1993a), embryo maturation and regeneration of whole plants (Mathews et al., 1993). To date, all reported protocols of cassava somatic embryogenesis induction were established on solid medium. The advantages of solid medium are well known (George, 1993). However, agar- solidified medium might present some undesirable features such as the presence of inhibitory substances (Powell \& Uhrig, 1987), low rate of molecules diffusion through the gel matrix (Romberger \& Tabor, 1971), water availability (Debergh et al., 1981) and agar nutrient composition that may alter the elemental composition of the medium (Singha et al., 1985). In some cases the use of liquid medium might overcome such problems, providing a more effective selection system as the explant is in direct contact with the culture medium.

Raemakers (1993) demonstrated that in cyclic somatic embryogenesis of cassava, liquid medium produced higher yield of embryos in comparison to solid medium. Recently, Taylor et al. (1996) established an embryogenic cell suspension on liquid SH medium (Schenk \& Hildebrandt, 1972). Based on this system, the production of the first transgenic cassava plant by particle bombardment was reported (Schöpke et al., 1996). Although Szabados et al. (1987) and Stamp and Henshaw (1987) suggested the possibility of somatic embryogenesis induction on liquid medium, conclusive data on this subject were not reported.

\footnotetext{
* Author for correspondence
} 
Recently, a new culture system has been successfully used on plant micropropagation programs. In such system, explants were cultured on a flat microporous polypropylene membrane floating in direct contact with the liquid medium. On plant micropropagation studies, this culture system has shown better results when compared to cultures conducted on either liquid and solid medium (Hew et al., 1990; Young et al., 1991; Desamero et al., 1993; Watad et al., 1995). However, it has never been tested in studies on induction and regeneration of somatic embryos.

In the present work, we describe the induction of organized embryogenic structures (OES) in leaf explants of cassava in liquid medium associated to floating membranes in comparison to solid medium. Different concentrations of 2,4-D were tested in both systems.

\section{MATERIALS AND METHODS}

In vitro cultured plants of the cassava genotype MCol 22 were obtained from the International Center for Tropical Agriculture (CIAT), Colombia. This genotype is commonly utilized for studies on somatic embryogenesis of cassava. Leaf lobes (3-5 $\mathrm{mm}$ of length) from in vitro cultured plants were used as explant source, according to Roca et al. (1984).

The culture medium consisted of MS salts (Murashige \& Skoog, 1962), supplemented with $0.5 \mathrm{mg} . \mathrm{L}^{-1}$ thiamine- $\mathrm{HCl}, 0.5 \mathrm{mg} . \mathrm{L}^{-1}$ pyridoxine, $0.5 \mathrm{mg} . \mathrm{L}^{-1}$ nicotinic acid, $100 \mathrm{mg} . \mathrm{L}^{-1}$ myoinositol, $2 \%$ sucrose and 2.5 g. $\mathrm{L}^{-1}$ Phytagel $^{\mathrm{TM}}$ as gelling agent for solid medium. 2,4-D was added to the media at different concentrations $(9,18$ and $36 \mu \mathrm{M})$. The $\mathrm{pH}$ was adjusted with $\mathrm{KOH}$ to 5.7 and both liquid and solid medium were distributed in $50 \mathrm{ml}$ aliquots into Magenta ${ }^{\mathrm{TM}}$ GA-7 vessels (Fig. 1A). The medium was autoclaved for $20 \mathrm{~min}$ at $121^{\circ} \mathrm{C}$. Cultures were kept in the dark at $28 \pm 1^{\circ} \mathrm{C}$. After 21 days, cultures were evaluated for the formation of organized embryogenic structures (OES) which were characterized by their smooth surface and highly organized development, and the formation of non-embryogenic friable callus
(NEFC) - callus of rapid growth visible in the early stages of culture. The frequency of explants containing OES was also scored.

A completely randomized experimental design was used. Each treatment consisted of 5 replications of 5 explants. OES obtained in both culture systems were transferred to maturation medium, according to Mathews et al., (1993) with minor modifications. The modified medium consisted of MS basal salts supplemented with $0.5 \mathrm{mg} . \mathrm{L}^{-1}$ thiamine-HCl, $0.5 \mathrm{mg} . \mathrm{L}^{-1}$ pyridoxine, $0.5 \mathrm{mg} . \mathrm{L}^{-1}$ nicotinic acid, $100 \mathrm{mg} . \mathrm{L}^{-1}$ myoinositol, $3 \%$ sucrose, $2.5 \mathrm{~g} . \mathrm{L}^{-1}$ Phytagel $^{\mathrm{TM}}$ and 5 g. $\mathrm{L}^{-1}$ active charcoal. Some of the maturated embryos were transferred to germination medium which consisted of MS salts supplemented with $0.5 \mathrm{mg} . \mathrm{L}^{-1}$ thiamine- $\mathrm{HCl}$, $0.5 \mathrm{mg} . \mathrm{L}^{-1}$ pyridoxine, $0.5 \mathrm{mg} . \mathrm{L}^{-1}$ nicotinic acid, $100 \mathrm{mg} . \mathrm{L}^{-1}$ myo-inositol, $2 \%$ sucrose and 2.5 g.L $\mathrm{L}^{-1}$ Phytagel $^{\mathrm{TM}}$. After 15-20 days of culture, regenerated whole plants were transferred to greenhouse.

\section{RESULTS AND DISCUSSION}

Plant micropropagation systems on liquid medium associated to membrane rafts has been successfully used in several works (Watad et al., 1995; Desamero et al., 1993; Adelberg et al., 1992). However, as far as we know this is the first report describing the use of such system for somatic embryogenesis induction.

Although all explants cultivated in both systems tested in this work showed the formation of OES (Fig. 1B and 2), the best response were obtained using solid medium supplemented with $36 \mu \mathrm{M}$ 2,4-D, where approximately $50 \%$ of the explants were able to form embryos (Fig. 2). These results confirmed the data previously reported by Li et al. (1998) also using the genotype MCol 22. Similar results were reported by Szabados et al. (1987), with the genotype MCol 1505. When leaf explants were cultured on liquid medium associated to membranes rafts, the best results were achieved at $9 \mu \mathrm{M} 2,4-\mathrm{D}$ with $30 \%$ of explants with OES. While the number of explants presenting OES was higher in solid medium in all concentrations of 2,4-D (Fig. 2), 
the higher degree of OES formation (amount of OES/explant) was observed in liquid medium with low concentrations of 2,4-D (9 and $18 \mu \mathrm{M}$ ) (Table 1). Using liquid medium associated
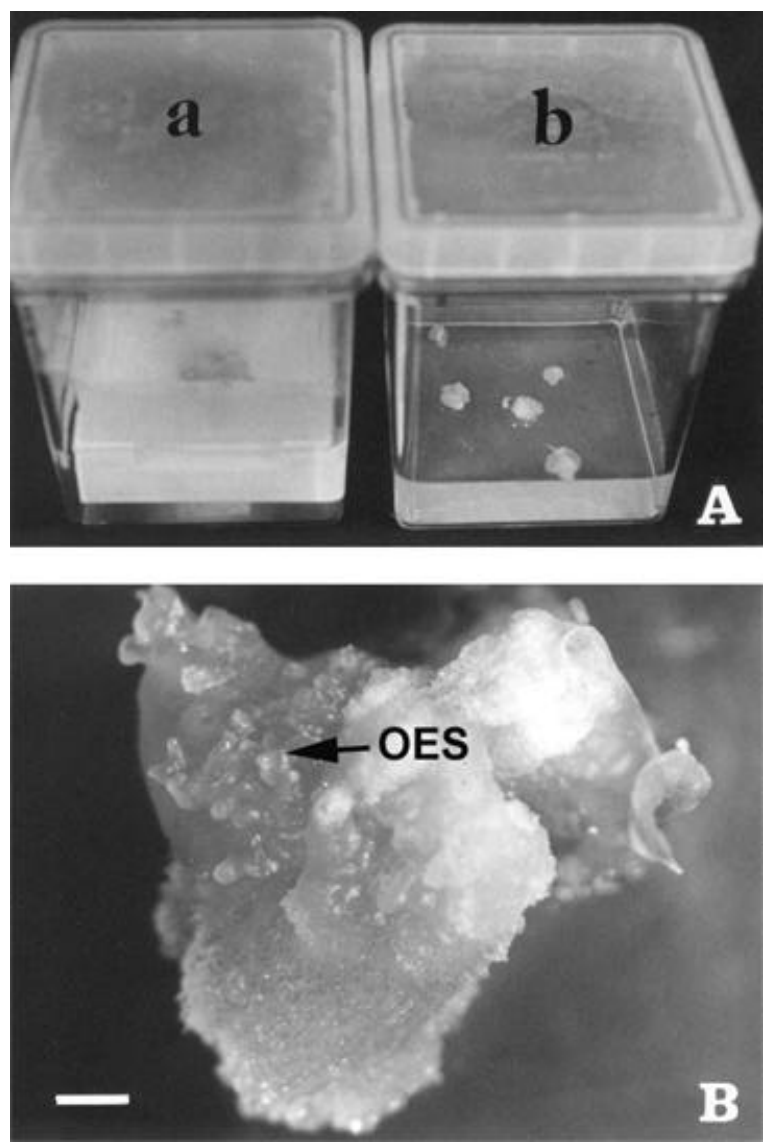

Figure 1. A) Explants after 21 days in liquid medium associated to membrane rafts (a) and in solid medium (b). B) OES obtained in liquid medium $($ Bar $=2 \mathrm{~mm})$.

to membrane rafts for micropropagation of Aconitum napellus, Watad et al. (1995) demonstrated that higher number of shoots were obtained at low concentration of growth regulators in comparison to agar-solidified medium. It is known that agar gel may restrict the diffusion of large molecules (Romberger \& Tabor, 1971) as well as inorganic substances (Faye et al., 1986). Therefore, such response may be due to the better availability of nutrients and growth regulators in the liquid medium.

The use of membrane rafts makes shaking of the cultures unnecessary. Raemakers et al. (1993b) showed that after three consecutive cycles of somatic embryogenesis in cassava, the yield of embryos produced in liquid medium was higher

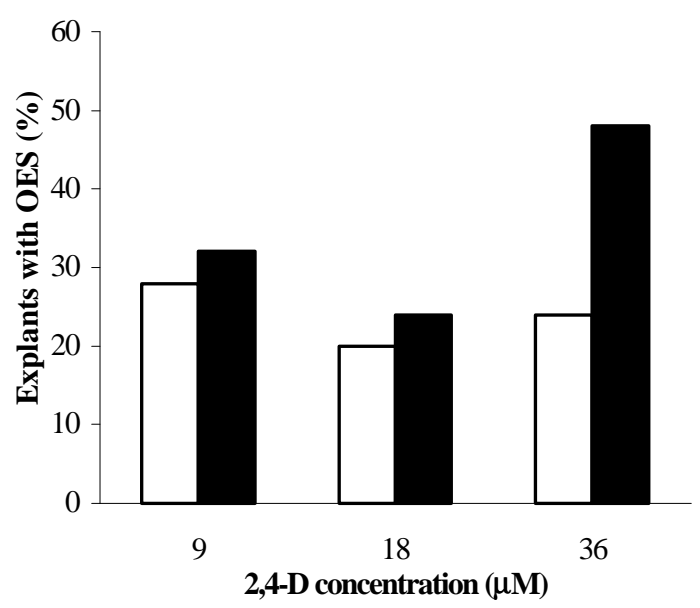

than in solid medium.

Figure 2. Effect of 2,4-D on the frequency of OES formation after 21 days of culture in solid medium $(\square)$ and liquid medium/membrane rafts ( $\square$ ).

According to the authors, development of embryos in solid medium could be overcome by the proliferation of callus on the explant. In order to remove the calli, a period of culture in liquid medium under agitation was required. In the present study, the use of membrane rafts for inducing embryogenic cultures reduced proliferation of nonembryogenic callus when compared to solid medium (Table 1).

Table 1. Formation of tissue types from leaf lobe explants with different concentrations of 2,4-D in two culture system, after 21 days.

\begin{tabular}{cccc}
\hline $\begin{array}{c}2,4-D \\
(\mu \mathrm{M})\end{array}$ & $\begin{array}{c}\text { Culture } \\
\text { medium }\end{array}$ & $\begin{array}{c}\text { Degree of } \\
\text { NEFC } \\
\text { formation }\end{array}$ & $\begin{array}{c}\text { Degree of } \\
\text { OES } \\
\text { formation }\end{array}$ \\
\hline \multirow{2}{*}{9} & Solid & ++ & ++ \\
& Liquid & + & ++++ \\
18 & Solid & +++ & ++++ \\
& Liquid & ++ & +++++ \\
36 & Solid & +++ & +++ \\
& Liquid & ++ & +++ \\
\hline
\end{tabular}

NEFC: Nonembryogenic friable callus; OES: Organized embryogenic structures. Degree of formation assessed from: $+=$ minimum (up to $25 \%$ of total tissue produced) to +++++ $=$ maximum (greater than $75 \%$ of total tissue produced).

No visible differences were observed between the development of regenerated plants derived 
from OES obtained in solid and liquid medium associated to membrane rafts, including embryo maturation and germination stages (data not shown).

According to our results, cultures in liquid medium associated to membrane rafts were suitable for OES induction, specially regarding the amount of OES/explant. However, this system presented some disadvantages in comparison to solid medium. Its initial cost was higher and cleaning of membranes from eventual contamination was difficult and time consuming. When analysed altogether this system, although innovative and suitable for other tissue culture techniques (i.e. micropropagation of some plant species), was not distinctly superior to solid medium for induction of somatic embryogenesis in cassava.

\section{ACKNOWLEDGEMENTS}

Elizabete K. Takahashi was supported by a scholarship from CAPES.

\section{RESUMO}

O objetivo deste estudo foi comparar a indução de embriogênese somática em mandioca (Manihot esculenta Crantz) utilizando o sistema de cultivo em meio líquido associado com membranas flutuantes com meio sólido, ambos suplementados com diferentes doses de 2,4-D. Utilizando membranas flutuantes, o melhor resultado foi obtido na concentração de $9 \mu \mathrm{M}$ 2,4-D, onde apenas $28 \%$ dos explantes foliares apresentaram estruturas embriogênicas organizadas (OES). Por outro lado, em explantes cultivados em meio sólido suplementado com 36 $\mu \mathrm{M}$ de 2,4-D a frequência de OES foi de $50 \%$. Embora a frequência de indução embriogênica tenha sido inferior em meio líquido associado com membranas flutuantes, a quantidade de OES por explante foi igual ou superior ao do meio sólido em todas as concentrações de 2,4-D testadas. Baseado nestes resultados, e considerando o elevado custo das membranas, este sistema de cultura não apresentou vantagens significativas para indução de embriogênese somática em mandioca em relação ao meio sólido.

\section{REFERENCES}

Adelberg, B. J.; Desamero, N.; Hale, A. \& Young, R. (1992), Orchid micropropagation on polypropylene membranes. Amer. Orch. Soc. Bull., 61, 688-695.

Debergh, P.; Harbaqui, Y.; Lemeur, R. (1981), Mass propagation of globe artichoke (Cynara scolymus): Evaluation of different hypotheses to overcome vitrification with special reference to water potential. Physiol. Plant., 53, 181-187.

Desamero, N. V.; Adelberg, J. W.; Hale, A.; Young, R. E. \& Rhodes, B. B. (1993), Nutrient utilization in liquid/membrane system for watermelon micropropagation. Plant Cell, Tiss. Org. Cult., 33, 265-271.

Faye, M.; David, A. \& Lamant, A. (1986), Nitrate reductase activity and nitrate accumulation in in vitro produced axillary shoots, plantlets and seedlings of Pinus pinaster. Plant Cell Rep., 5, 368-371.

George, E. F. (1993), Plant propagation by tissue culture. Part 1. In- The technology. Exegetics Ltd, Edington, Wilts, England.

Hew, C. S.; Chan, Y. S.; Lee, Y. K. \& Chia, T. F. (1990), Culture of orchid tissue on polypropylene membrane. Mal. Orch. Rev., 24, 78-81.

Li, H.-Q; Guo, J. -Y; Huang, Y. -W; Liang, C. Y; Liu, H.-X; Potrykus, I. \& Puonti-Kaerlas, J. (1998), Regeneration of cassava plants via shoot organogenesis. Plant Cell Rep., 17, 410-414.

Mathews , H.; Schöpke, C.; Carcamo, R.; Chavarriaga, P.; Fauquet, C. \& Beachy, R. N. (1993), Improvement of somatic embryogenesis and plant recovery in cassava. Plant Cell Rep., 12, 328-333.

Murashige, T. \& Skoog, G. F. (1962), A revised medium for rapid growth and bioassays with tobacco tissue cultures. Physiol. Plant., 15, 473-497.

Powell, W. \& Uhrig, H. (1987), Anther culture of Solanum genotypes. Plant Cell, Tiss. Org. Cult., 11, 13-24.

Raemakers, C. J. J. M. (1993), Primary and cyclic somatic embryogenesis in cassava 
(Manihot esculenta Crantz). Thesis Agricultural University Wageningen, Netherlands.

Raemakers, C. J. J. M.; Schavemaker, C. M.; Jacobsen, E. \& Visser, R. G. F. (1993) Improvements of cyclic somatic embryogenesis in cassava. Plant Cell Rep., 12, 226-229.

Roca, W. M.; Rodrígues, J. A.; Mafla G. \& Roa, J. (1984), Procedures for recovering cassava clones distributed in vitro. CIAT, Colombia.

Roca, W. M.; Henry, G.; Angel, F. \& Sarria R. (1992), Biotechnology research applied to cassava improvement at the International Center of Tropical Agriculture (CIAT). Agbiotech News Inf., 4, 303-308.

Romberger, J. A. \& Tabor, C. A. (1971), The Picea abies shoot apical meristem in culture. I. Agar and autoclaving effects. Amer. J. Bot., 58, 131-140.

Schenk, R. \& Hildebrandt, A. (1972), Medium and techniques for induction and growth of monocotyledonous and dicotyledonous plant cell cultures. Can. J. Bot., 50, 199-204.

Schöpke, C.; Taylor, N.; Cárcamo, R.; Konan, N. D. K.; Marmey, P.; Henshaw, G. G.; Beachy, R. N. \& Fauquet, C. (1996), Regeneration of transgenic cassava plants (Manihot esculenta Crantz) from microbombarded embryogenic suspension cultures. Nature Biotech., 14, 731-735.

Singha, S.; Townsend, E. C. \& Oberly, G. H. (1985), Mineral nutrient status of crabapple and pear shoots cultured in vitro on varying concentrations of three commercial agars. $J$. Amer. Soc. Hort. Sci., 11, 407-411.

Stamp, J. A. \& Henshaw, G. G. (1982), Somatic embryogenesis in cassava. $Z$. Pflanzenphysiol., 105, 183-187.

Stamp, J. A. \& Henshaw, G. G. (1987), Secondary somatic embryogensis and plant regeneration in cassava. Plant Cell, Tiss. Org. Cult., 10, 227-233.

Szabados, L.; Hoyos, R. \& Roca, W. (1987), In vitro somatic embryogenesis and plant regeneration of cassava. Plant Cell Rep., 6 , 248-251.

Taylor , N. J.; Edwards, M.; Kiernan, R. J.; Davey, C. D. M.; Blakesley, D. \& Henshaw, G. G. (1996), Development of friable embryogenic callus and embryogenic suspension culture systems in cassava (Manihot esculenta Crantz). Nature Biotech., 14, 726-730.

Watad, A. A.; Kochba, M.; Nissim, A. \& Gaba, V. (1995), Improvement of Aconitum napellus micropropagation by liquid culture on floating membrane rafts. Plant Cell Rep., 14, 345-348, 1995.

Young, R. E., Hale, A, Campeer, N. D., Keese, R. J. \& Adelberg, J. W. (1991), Approaching mechanization of plant micropropagation. Trans. ASAE, 34, 328-333.

Ziv, M. (1991), Quality of micropropagated plants - vitrification. In Vitro Cell Dev. Biol. 27P, 64-69. 